\title{
Therapeutic effects of Ozone therapy in adult periodontitis treatment, subtypes I and II.
}

\author{
Judit Martinez-Abreu ${ }^{1}$, Mark T. Weisser ${ }^{2}$, Silvia Menendez-Cepero ${ }^{3}$.
}

1 Dra. in Stomatology. Second Degree Specialist in Periodontics. Master in Sciences in Attention of Dental Urgencies. Master in Sciences in Community Buccal Health. Director of the Career in Stomatology. Auxiliary Professor. University of Medical Sciences of Matanzas, Cuba.

2 Odontologist. Pathfinder Institute. Santa Bárbara, California. USA

3 Dr. in Chemical Sciences. Full Researcher. Centro Nacional de Investigaciones Científicas (CNIC), Havana, Cuba

\section{ABSTRACT}

Introduction: Conventional treatments of the periodontitis rely on surgery and antibioticotherapy. The properties of the ozone offer a more innocuous and more economic new alternative therapeutic.

Objective: to evaluate the effectiveness of the ozone therapy in the treatment of periodontitis type I and II, and to identify the adverse events

Methods: It was carried out a clinical trial, phase III, randomized, controlled and to simple blind in patients that went to Odontological Clinic "III Congress of PCC" of Matanzas, January 2013 - January 2015. The sample belonged to 50 patients, divided in 5 groups of 10 patients each one: Group A - Treaties with ozone gas. Group B - OLEOZON®. Group C - ozonized water. Group D - treatment of ozone combined with the three modalities (gas, ozonized water and OLEOZON®. Group Z (control) - conventional treatment. The groups A, B, C and D were the experimental groups. Clinic and microbiolgical evaluation was measures. Effectiveness of the treatment, and adverse events were evaluated. The results showed up in graphics, the percentage and Square Chi were used. The ethical principles were completed.

Results: Clinical evaluation went satisfactory to the month of the treatment in $84,6 \%$ of the studied places, with better results in the group D (96\%), with significant differences between the experimental groups and the control. The microbiological evaluation was satisfactory and increased to $85,4 \%$ to the six months of the study. The experimental group D prevailed $(96,6 \%)$. The effectiveness was good in $85,4 \%$ of the sample, prevailing in the experimental group D with $96,6 \%$, followed by the group A. The percentage of adverse events was low, $1,5 \%$.

Conclusions: The clinical and microbiological evaluation showed satisfactory results, associated to a low percentage of adverse events (with gas ozone only). The combined ozone therapy was the most effective treatment for this type of periodontitis.

Keywords: ozone therapy, treatment, periodontitis

\section{INTRODUCTION}

Advances in medicine as a science, in the world, have incorporated knowledge and practices, whose results evidence to be of high value for development and progress of humanity ${ }^{1}$.

\section{Authors Information}

\section{E-mail address: jmabreu.mtz@infomed.sld.cu}

Among contemporary medicine trends stands out, with an increasing dynamism in recent years, incorporation of natural and traditional medicine to professional practice, not as an alternative method but as true discipline which is necessary to constantly study, improve and develop, due to its proven ethical and scientific advantages.

This medicine, internationally known as alternative, energetic, natural, complementary or holistic is a reality made present in the whole world and is part of each country's cultural heritage. It uses practices 
that have varied from country to country and generation after generation, for hundreds of years before development of current conventional medicine.

In Cuba, it is considered a medical discipline, recognized by the National Ministry of Public Health (Ministerio Nacional de Salud Pública) (MINSAP) according to the needs identified by the health services, for which is also of great significance for the knowledge and application of promotion procedures and techniques of health, disease prevention, diagnose, healing and rehabilitation. Therefore, in searching for better quality of life, the use of natural medicaments and other therapeutic resources readily available at low cost and within everybody's reach is generalized ${ }^{1,2}$.

Since 1990 a development commission of traditional and natural stomatology was created in the National Stomatology Division. This commission counted on 3 sub commissions: one dealing with development of green medicine; another, acupuncture (including finger puncture) ${ }^{1}$ and the third encompassing other modalities among which is ozone therapy, the subject of this study $1,3,4$.

In Cuba application of ozone therapy in the different forms it presents, as gas and ozonized oil and water ${ }^{5-14}$, has been under research for over 30 years now by the National Center for Scientific Research (Centro Nacional de Investigaciones Científicas) (CNIC).

Ozone has a number of biological effects, such as bactericide, fungicide and virucide. It also improves blood circulation, increases capacity of oxygen absorption in the erythrocytes, stimulates processes of oxygen metabolization reactivating various biologic cycles and activating the antioxidant defense systems; besides, it has healing, disinfecting, sterilizing, anti-inflammatory and immodulator effects of the biologic response ${ }^{6}$.

Introduction of ozone in the field of Medicine conditioned the search for new therapeutic strategies, taking into consideration the chemical properties of this gas and its interaction with the biomolecules. In this context, vegetable oils have become an adequate means for the local treatment of a number of diseases in Medicine, as well as in Stomatology11,15-19. The most widely used oil is the olive oil; in our country, the one used is the sunflower oil. OLEOZON® (ozonized sunflower oil) has a great germicide power (against virus, bacteria, fungi and parasites) and a certain anti inflammatory and anti oxidant character. ${ }^{20,21}$ It has demonstrated its effectiveness in different pathologies. ${ }^{11,15-19} \quad$ Besides its economic advantages, it has successfully passed preclinical trials of dermal irritability, as well as mutagenicity and teratogenicity trials $22-26$.

Chronic immune inflammatory periodontal disease is generically classified as either gingivitis or periodontitis, being the latter the most advanced form in which gingival inflammation is accompanied by the presence of real pockets and bone loss, which if is not treated properly and timely will lead to dental mortality and functional incapacity 27 .

There are various types of periodontitis, of which the most frequent is Adult periodontitis. A subdivision has been made within this classification proposing 4 subtypes 28 :

I: Periodontal pockets of up to $3 \mathrm{~mm}$ depth with presence of blood, periodontal pathogens, according to the microbiologic analysis (BANA Test or the microscope)

II: Periodontal pockets of up to $4 \mathrm{~mm}$ with presence of blood, slight quantity of calculus, periodontal pathogens, and there could be incipient bone loss or not, according to microbiologic analysis (BANA Test or the microscope)

III: Periodontal pockets of up to 5 and $6 \mathrm{~mm}$ with presence of blood, moderate quantity of calculus, moderate bone loss (X Rays), periodontal pathogens, according to microbiologic analysis (BANA Test or the microscope)

III+: Same characteristics as subtype III but with periodontal pockets of up to $7 \mathrm{~mm}$.

IV: Periodontal pockets of up to $9 \mathrm{~mm}$ with presence of blood, high quantity of calculus, advanced bone loss ( $\mathrm{X}$ Rays), periodontal pathogens, according to microbiologic analysis (BANA Test or the microscope)

IV+: Serious periodontal condition with very reserved prognosis and treatment including exodontia of some teeth.

Pathogenesis of periodontitis is multifactorial and is closely linked to periodontal pathogenic microorganisms and immune system of the human body 29 . It has been studied the way oxidative stress favors its occurrence and worsening ${ }^{30}$.

Besides, conventional treatment relies on surgery and antibiotic therapy, which supposes more expenses, possible adverse reactions and occurrence of resistant strains. 
Taking into consideration the therapeutic properties of ozone therapy, the objective of the study was to assess the efficacy of ozone, OLEOZON and ozonized water in the treatment of adult periodontitis types I and II and also to identify the possible adverse events.

\section{PATIENTS AND METHODS}

A randomized, controlled and single blind clinical trial phase III was carried out to evaluate the effects of ozone therapy during the treatment of adult periodontitis types I and II.

Patients diagnosed with adult periodontitis types I and II, over 35 years of age and of any sex or skin color who gave their informed consent to participate in the research were included. Patients with neoplasia antecedents or having received chemotherapy treatment or radiations, with nephropathy, transplantations, cardiopathies, blood dyscrasias, metabolic disorders and other suffering that may interfere with normal evolution of the tissues were excluded. Patients who refused to continue in the research, changed their home address or were in hospital and unable to continue the treatment plan or died by causes not related to the research exited the study.

The sample was made up of 50 patients, who were divided at random (according to software EPIDAT 3.1 ), into 5 groups of 10 patients each:

Group A - Treated with ozone gas.

\section{Group B - Treated with OLEOZON®}

Group C - Treated with ozonized water

Group D - Treated with ozone treatment combined with the three modalities (gas, ozonized water and OLEOZON®

Group Z (control) - Treated with conventional treatment.

Groups A, B, C and D were experimental groups.

All patients underwent the initial phase of periodontal treatment (elimination and/or control of local irritants and other risk factors). After a month of evolution they were given the following procedures:

Groups A, B, C y D underwent radicular scraping and smoothing in the periodontal pockets treated. Subsequently, they were applied ozone therapy in the following way:

Group A: was applied ozone gas for three seconds in each real pocket detected at examination.
Group B: was applied two drops of OLEOZON ${ }^{\circledR}$ in each real pocket detected, under previous relative isolation.

Group C: was irrigated with ozonized water in the pockets with hypodermic syringes, $20 \mathrm{cc}$ in each.

Group D: was applied a combined treatment in the following order: first, irrigation with ozonized water, then, application of ozone gas and after that, application of OLEOZON.

Group Control $\mathrm{Z}$ underwent sessions of radicular scraping and smoothing as conventional treatment an then it was applied irrigation with physiological saline solution without applying any other medicament.

Treatments with ozone therapy were applied during a month at intervals of 7 days between each session in the case of gas and ozonized water. Ozonized oil was applied twice daily, by the patient itself, except for the day of evolution recording and assessment when it was applied by the researcher, like the other two modalities.

The criteria for evaluation taken into consideration were clinical and microbiologic:

\section{1- Clinical Evolution}

Satisfactory: When signs and symptoms are eliminated.

Unsatisfactory: When there is still some presence of signs or symptoms or the patient remains the same or his condition worsens.

2-Microbiologic evaluation (according to the BANA-Zyme test result)

Satisfactory: When there is no change in color, meaning less than 10000 periodontal pathogens present.

Unsatisfactory: When there are changes of color (light or dark blue) which means over 10000 periodontal pathogens present.

Efficacy was considered good fair or poor.

Good: When clinical and microbiologic evaluations were satisfactory.

Fair: When only one of them was good.

Poor: When both were unsatisfactory.

It was also taken into consideration the presence or not of adverse event, (according to what the patient reports). Examples of adverse event, according to studies in OLEOZON ${ }^{\circledR}$ carried out have been:(7-18) Cough, dry throat, shortness of breath, burning 
sensation, pruritus, pain, fever, edema and others. Patients were explained that if they felt some of these symptoms, they should go to the stomatologist at once.

The following variables were also studied:

Presence of gingivorrhagia at examination (yes or not), depth of periodontal pockets ( $3 \mathrm{~mm}$ or $4 \mathrm{~mm}$ ), osseous loss (according to x-ray image).

Evolution of the patients was recorded at the $7^{\text {th }}$, $14^{\text {th }}$ and $21^{\text {st }}$ days, of the month, at $3^{\text {rd }}$ and $6^{\text {th }}$ month and were assessed at the $6^{\text {th }}$ month. Values for the variables at the beginning of the study and at the $6^{\text {th }}$ month of treatment were compared

The principles of the Geneva Declaration adopted by the World Medical Association and the International Code of Medical Ethics were fulfilled. The core principles of the World Medical Association for biomedical research were taken into consideration: biomedical research coincides with scientific standards generally accepted, design and performance of research is clearly formulated in the research protocol, research was carried on by qualified persons, and its objective maintained a proportion related to the risk inherent to the individual. A previous review and careful study of the predictable risks in relation to possible benefits was carried out, integrity and privacy of the individual was maintained and informed consent was requested from the individuals by providing them with detailed information on the purpose of the research, its innocuousness, anonymity and independence to continue in the study.

The clinical assay was approved by the Scientific Council of the University of Medical Sciences of Matanzas, Cuba.
The source of information was data obtained from which a database on Excel 2010 was made. Statistical program SPSS 17 was used for data analysis and processing.

To summarize the information it was presented in contingency tables and the results obtained were compared; this was made with tabulations and calculus of percentage indicators aimed at corroborating the statistical relationship between variables with a Chi Square level of significance of $95 \%$.

\section{RESULTS}

The study sample was divided into age ranges (35-44, 45-54, 55-64, 65-74, 75-84, 85 and over) and according to sex (Chart 1).

It was observed a homogeneous distribution of the sample regarding age and sex with $50 \%$ masculine and $50 \%$ feminine. Ages were mainly of 35-44 and 45-54 years. There were no patients with ages over 65 years in the study.

Presence or not of gingivorrhagia at the beginning of the study is observed in Chart 2. Predominance of gingivorrhagia at examination was shown in $97 \%$ of the periodontal sites at the beginning of the study, with similar distribution among groups.

Presence of gingivorrhagia at the $6^{\text {th }}$ month of performing the different treatments is observed in Chart 2.1.

It was shown a predominance of sites without gingivorrhagia at the $6^{\text {th }}$ month of treatment, showing significant differences $(p<0,05)$ between the control group and the rest of the experimental groups. Control group $\mathrm{Z}$ maintained more sites with gingivorrhagia by $35 \%$, experimental group D (combined treatment) was the one which had the

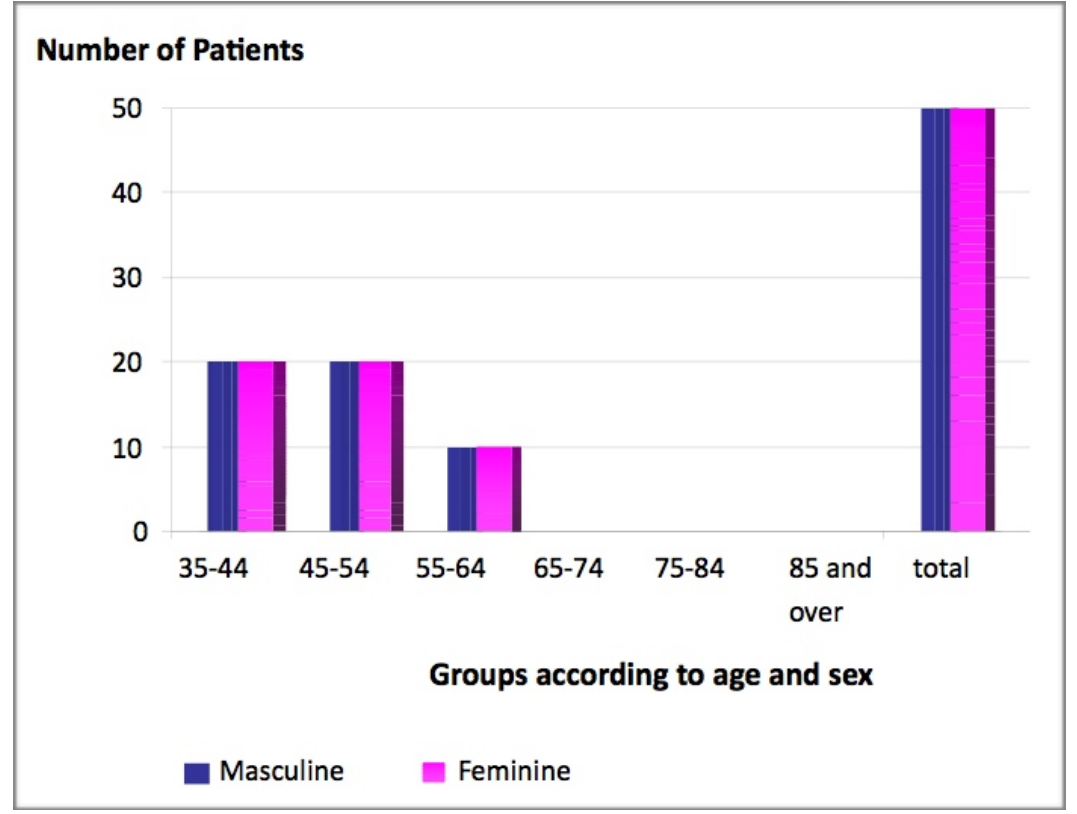

Chart 1. Distribution of the sample according to age and sex. 

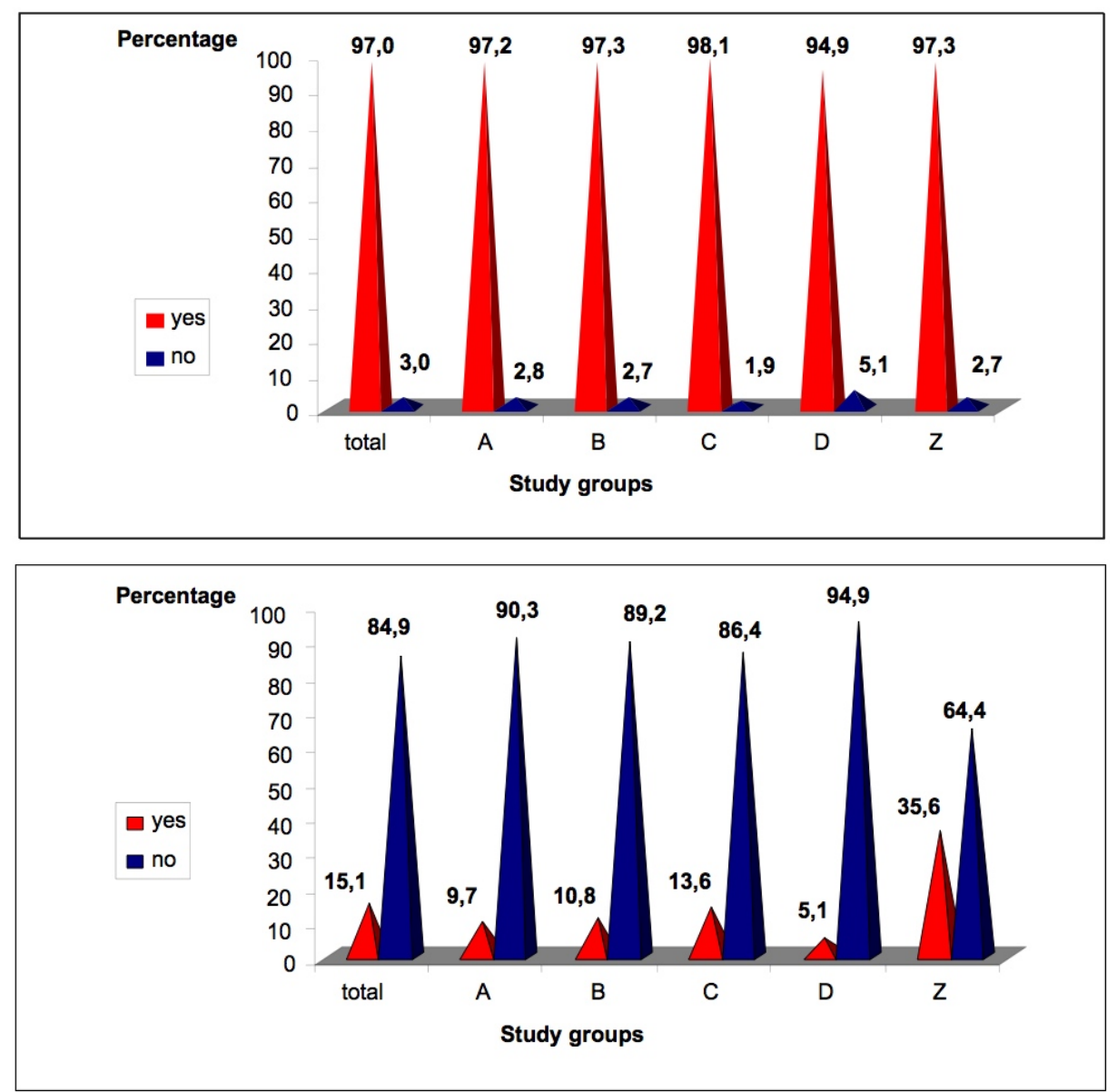

Chart 2. Periodontal sites with gingivorrhagia at examination at the beginning of the study.

Chart 2.1. Periodontal sites with gingivorrhagia at the 6th month of treatment.

$Z=64.041$ $p=0.000$ most periodontal sites without gingivorrhagia by $94.9 \%$.

Presence of periodontal pockets at the beginning of the study, according to the different treatments is observed in chart 3 .

Periodontal pockets of $4 \mathrm{~mm}$ showed a slight predominance at the beginning of the treatment (51, $5 \%$ ) in the sample total, more notable in experimental group A by $52,8 \%$.

Periodontal pockets behavior at the $6^{\text {th }}$ month of treatment is observed in Chart 3.1.

When comparing the experimental groups to the control group in relation to periodontal sites of 3 $\mathrm{mm}$ (without pockets), the showed predominance $(87,9 \%)$, being experimental group D (combined treatment) the most notable with a $97,2 \%$. However, the control group still maintained a $20 \%$ of pockets of $4 \mathrm{~mm}$ with significant differences $(p<0,05)$ as regards the experimental groups.

The result of osseous loss at the beginning of the different treatments is shown in Chart 4.
A slight osseous loss was appreciated in the sites studied at the beginning of the study $(17,5 \%)$, with a similar distribution among the groups studied.

The result of the osseous loss at the end of the different treatments is shown in Chart 4.1

However, at the $6^{\text {th }}$ month it was observed a decrease in the bone loss only by $2,6 \%$ of the sites that maintained $\mathrm{X}$ ray findings, more notable in control group by $6,9 \%$ and outstanding in experimental group D in which no patient showed $\mathrm{X}$ ray signs of osseous loss, followed by group $\mathrm{A}$ with only a $0,7 \%$.

Clinical evolution at the month and at the $6^{\text {th }}$ month of treatment is appreciated in charts 5, 5.1 and 5.2. A clinical evolution was shown at the month of treatment in the $84,62 \%$ of the patients studied, with better results in group D (96\%) which received the ozone therapy combined treatment with slight differences between experimental groups and the control group, obtaining a $77 \%$ in its clinical evolution (chart 5).

A satisfactory clinical evolution was observed at he $6^{\text {th }}$ month of treatment by $90,7 \%$ of the patients studied, with better results in experimental group D 


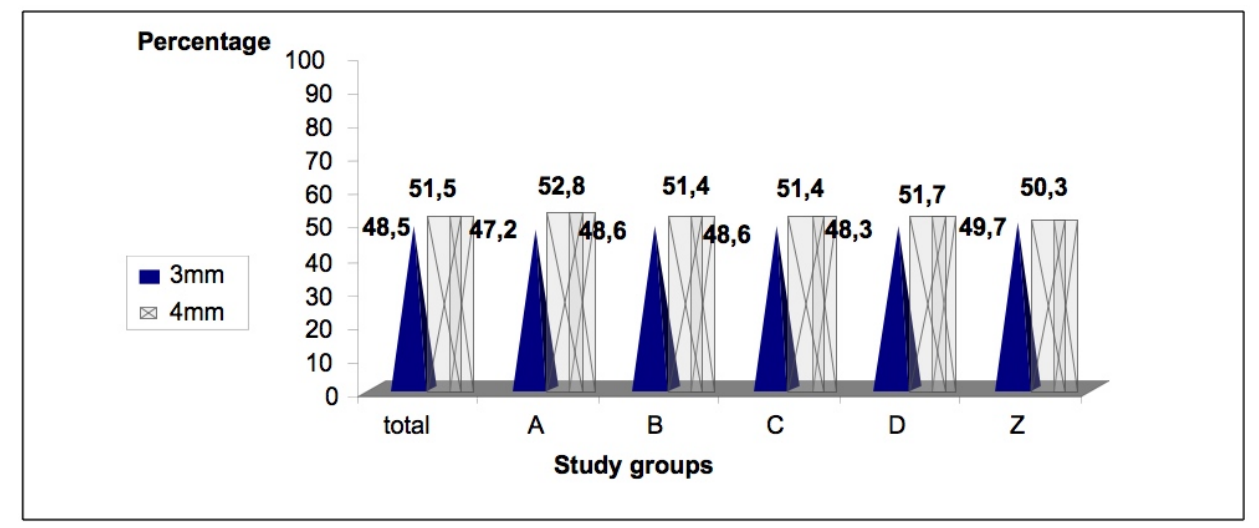

Chart 3. Periodontal sites and pockets according to the different groups at the beginning of the study.

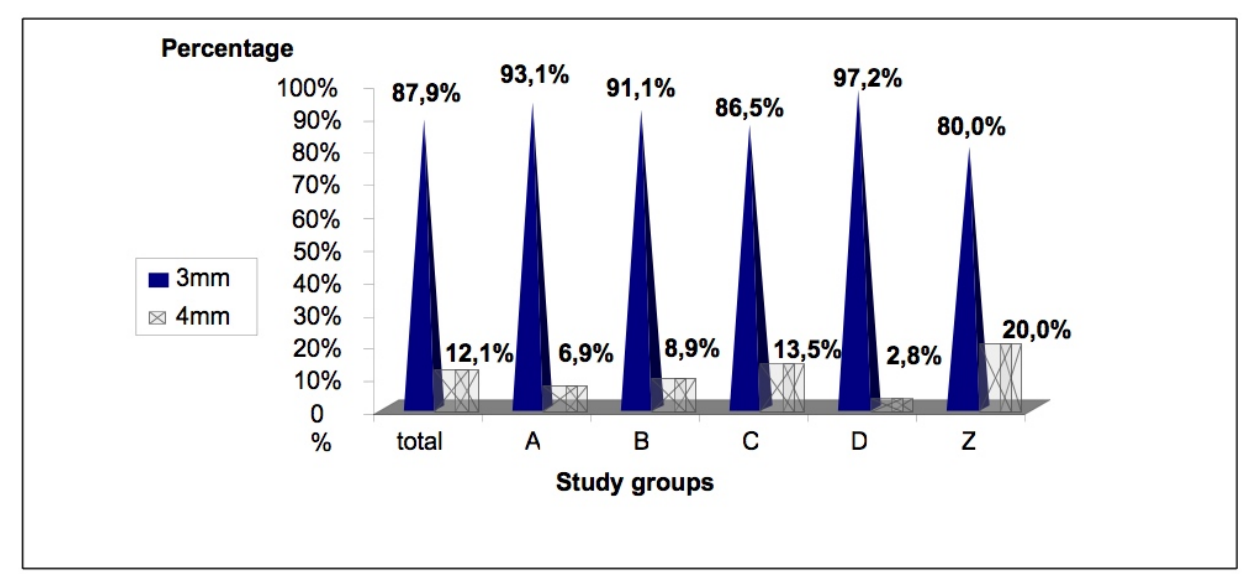

Chart 3.1. Periodontal sites and pockets, according to the different groups, at $6^{\text {th }}$ month of treatment.

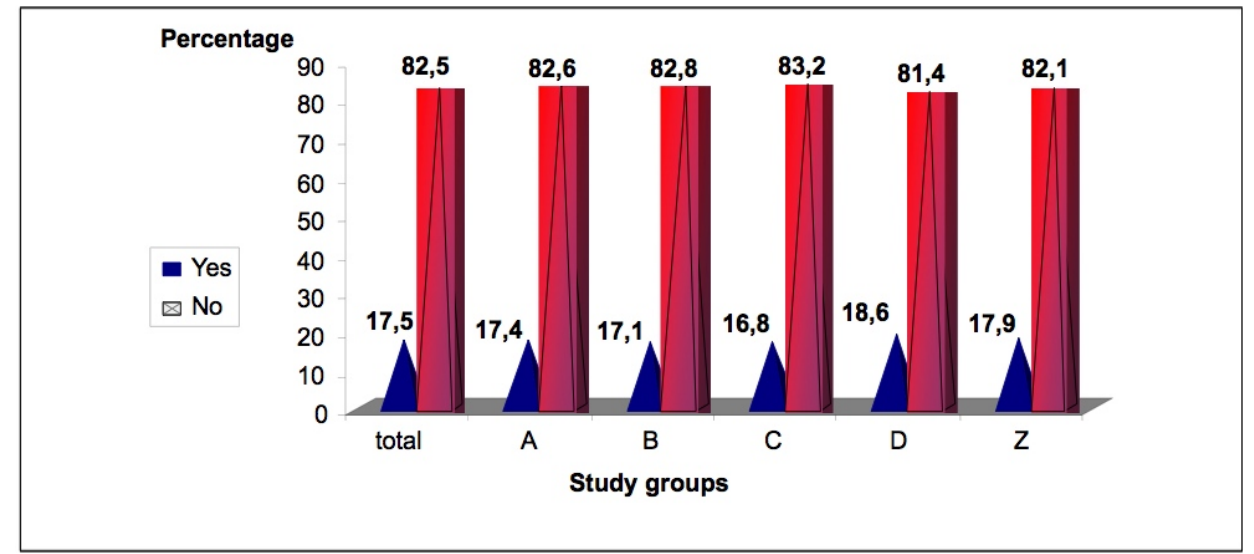

Chart 4. Osseous loss according to the group of treatment at the beginning of the study.

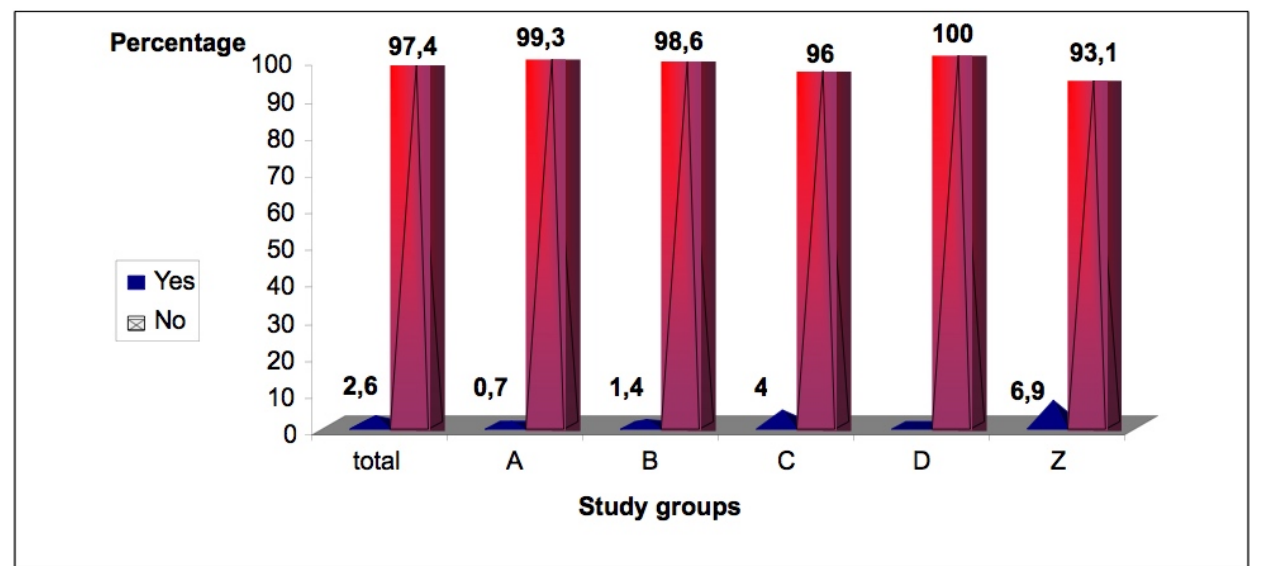

Chart 4.1. Osseous loss according to the groups of treatment at the $6^{\text {th }}$ month of study 
with a $100 \%$, followed by group A (99\%) with significant differences in relation to the control group which evidenced a vaguely satisfactory clinical evolution (74\%).

Chart 5.2 shows the comparison between clinical evolution at the month and at the $6^{\text {th }}$ month for experimental groups and control .

Table 1 showed results of analysis of comparing each group independently at the month and at the $6^{\text {th }}$ month, in relation to the satisfactory evolution.

When analyzing each group independently, significant statistical differences were found in groups $\mathrm{A}, \mathrm{B}$ and $\mathrm{D}$, in the first month and in the sixth month. Patients continued to improve even after completing the applications. Only treatment with ozonized water did not show a difference between the two evaluations.
Results of the microbiologic evolution are shown in the Charts 6 (beginning of the study) and 6.1 (at the $6^{\text {th }}$ month of treatment).

Satisfactory microbiologic evolution increased from $1,6 \%$ at the beginning of the study to $85,4 \%$ of the sample at the $6^{\text {th }}$ month of the study. Experimental group D was predominant which attained a 96, 6\% followed by A which made a $91,7 \%$. Group control obtained the least percentage with a $72,4 \%$.

When analyzing the microbiologic evolution (presence of periodontal pathogens, according to BANA-Zyme test) significant statistical differences were found between the control group $(Z)$ and the experimental groups.

Results from the evaluation of efficacy are shown in Chart 7. When evaluating efficacy, it was observed that treatment studied showed a good

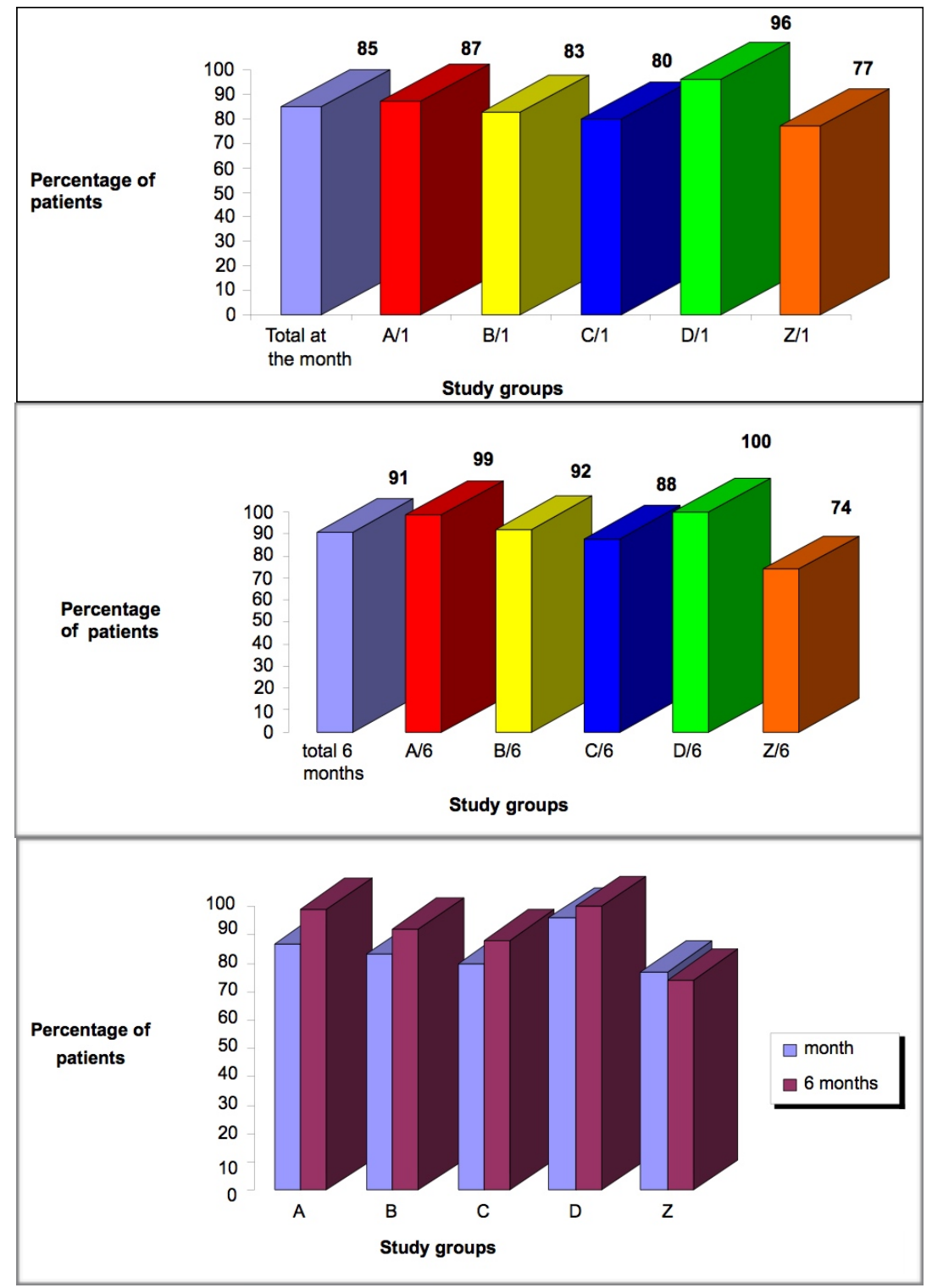

Chart 5. Satisfactory clinical evolution at the month according to the groups of treatment.

$Z=21,924 p=0,000$

Chart 5.1 Satisfactory clinical evolution at the $6^{\text {th }}$ month according to the group of treatment.

$Z=72,453$

$p=0,000$

Chart 5.2 Satisfactory clinical evolution at the month and a t the $6^{\text {th }}$ month, according to the group of treatment. 
Table 1. Satisfactory clinical evolution. Proportions at the month and at 6 th month compared according to the independent groups of treatment.

\begin{tabular}{|c|c|c|c|c|c|}
\hline $\begin{array}{l}\text { Groups of } \\
\text { treatment }\end{array}$ & month & 6 months & IC $(95,0 \%)$ & Statistical Z & Value $p$ \\
\hline$A$ & 86,9 & 98,6 & $-0,183-0,053$ & 3,6262 & 0,0003 \\
\hline B & 82,9 & 92,4 & $-0,177-0,014$ & 2,3140 & 0,0207 \\
\hline $\mathrm{C}$ & 80,4 & 87,8 & $-0,164 \quad 0,015$ & 1,5904 & 0,1118 \\
\hline $\mathrm{D}$ & 95,9 & 100,0 & $-0,081-0,002$ & 2,0627 & 0,0391 \\
\hline Z & 77,2 & 74,4 & $-0,078 \quad 0,133$ & 0,4117 & 0,6806 \\
\hline
\end{tabular}
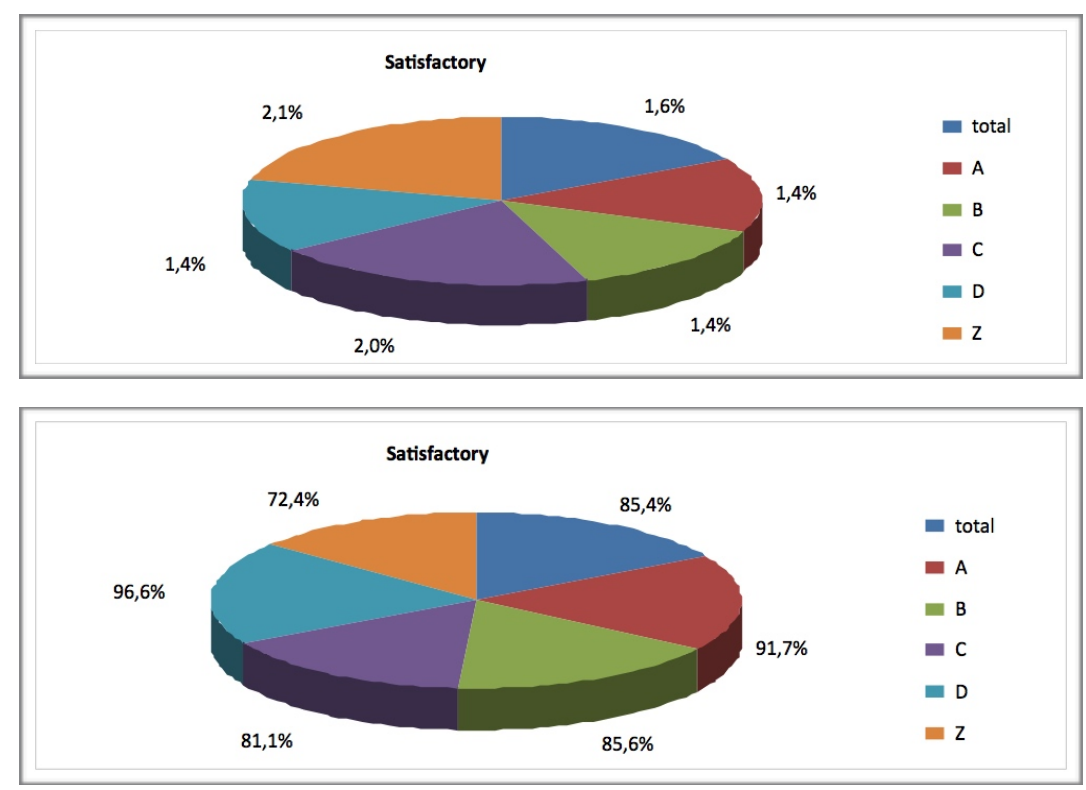

Chart 6. Satisfactory microbiologic evolution at the beginning of the study.

Chart 6.1 Satisfactory microbiologic evolution at the $6^{\text {th }}$ month of treatment.

$Z=40,921$ $\mathrm{p}=0,000$

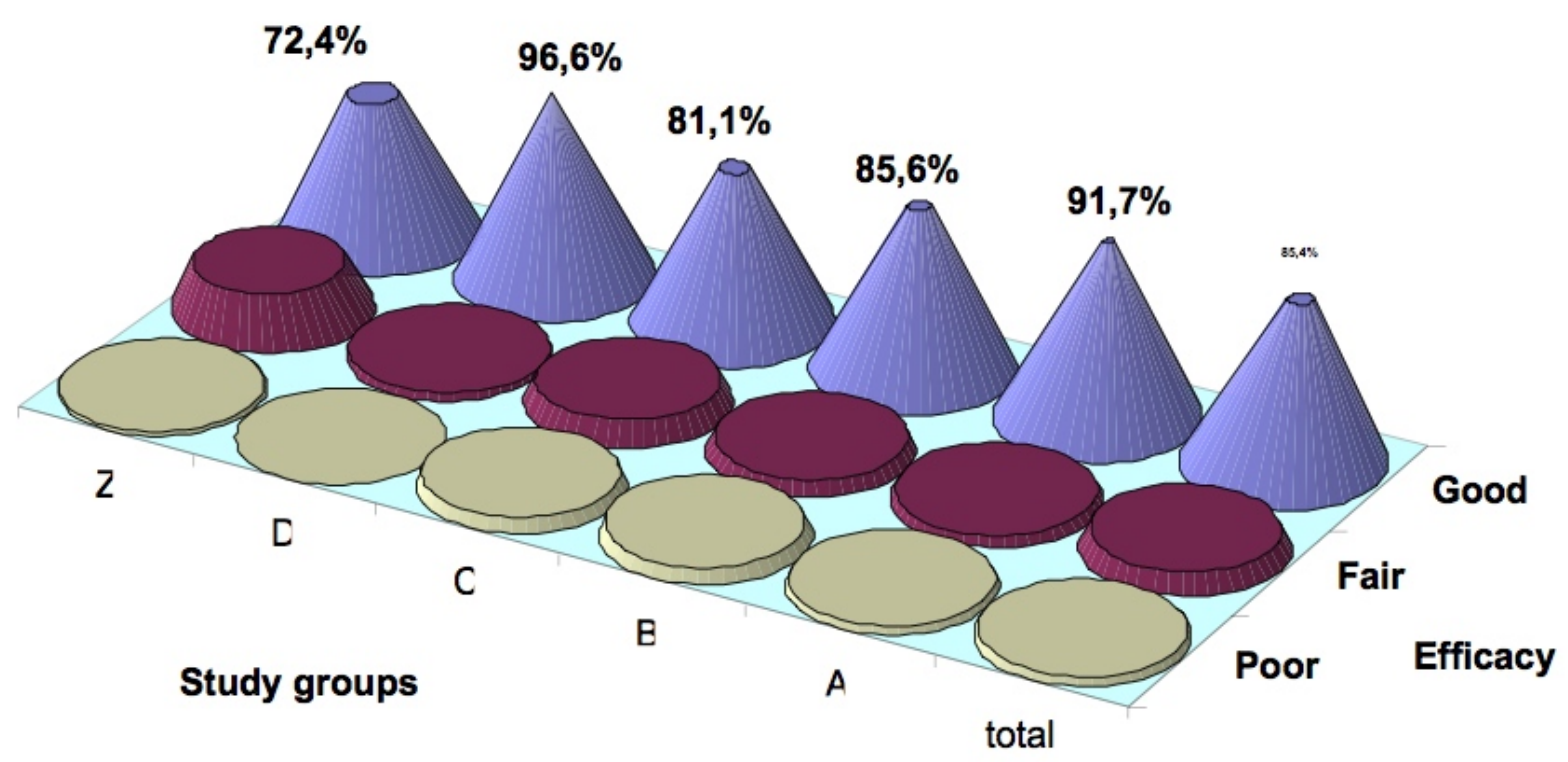

Chart 7. Efficacy of the different treatments studied. $Z=62,534 p=0,000$ 
efficacy of $85,4 \%$ in the total of the sample, in which experimental group D (combined ozone therapy treatment) was predominant by $96,6 \%$, following group A (treatment with ozone gas) with a $91,7 \%$ and being the least in control group $\mathrm{Z}$ with a $72,4 \%$. Significant statistical differences were obtained between the control group and the experimental groups.
The presence of adverse effects at the $6^{\text {th }}$ month of treatment completion was shown in Chart 8 .

Percentage of adverse effects, described as slight was very low (cough, dryness in the laryngeal region and pruritus), and related mainly to ozone gas. It corresponded to a $1,5 \%$ of the sample total, predominating in group A by $3,5 \%$.

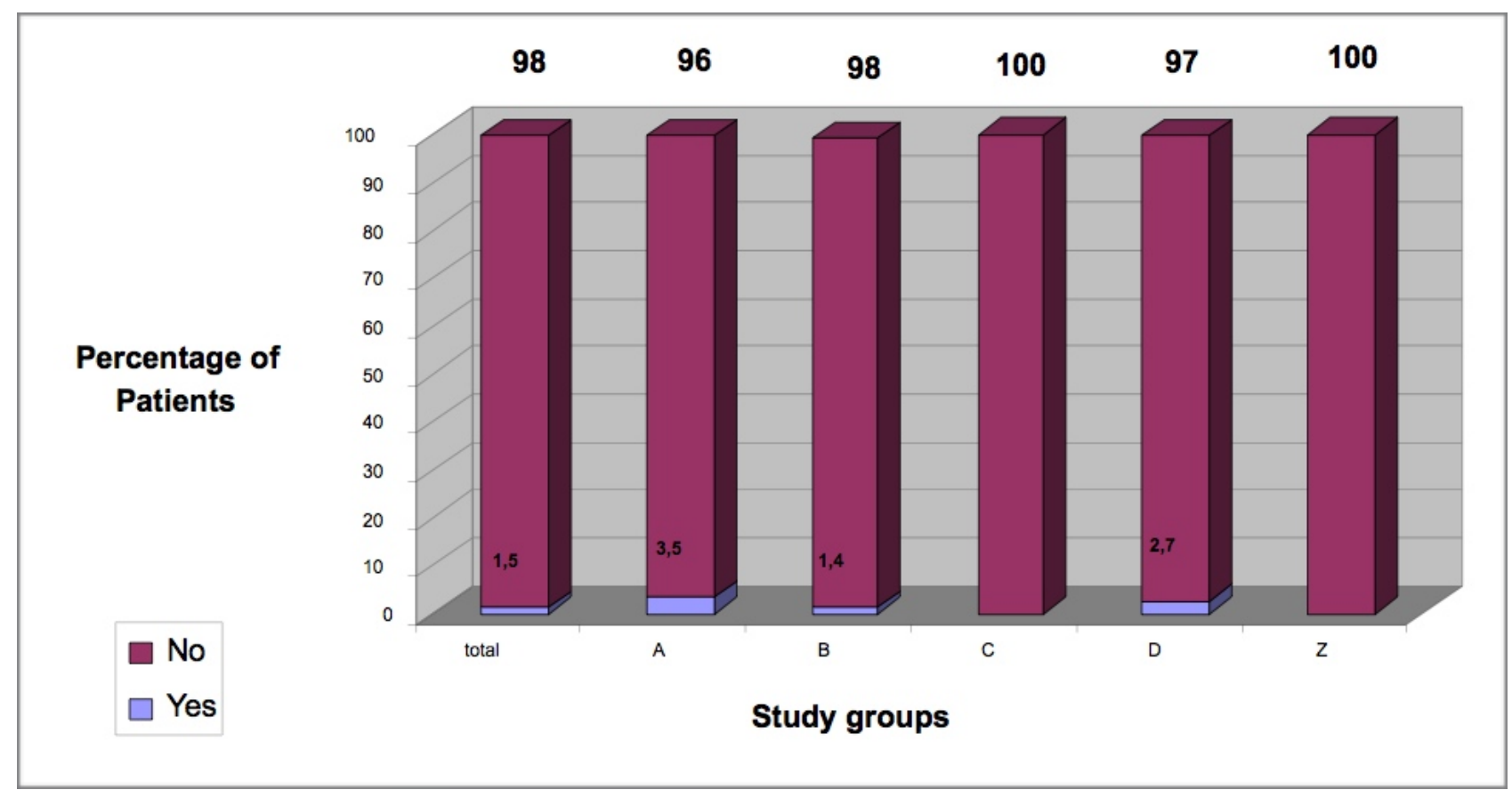

Chart 8. Presence of adverse events at the $6^{\text {th }}$ month of treatment completion.

\section{DISCUSSION OF RESULTS}

In the clinical trail, homogeneity was achieved in the groups regarding age and sex, an important element at evaluating results of treatments. Ages between 35-44 and 45-54 years predominated, corresponding to the epidemiological behavior stated at the beginning of the chronic destructive disease that begins at 35 years and worsens with ageing. Other studies show similar results in the composition of the sample. (31-38)

Gingivorrhagia is a clinical sign to bear in mind for it reveals the microbial activity and lysis of conjunctive tissue due to epithelial affectation and invasion of antigens of subgingival microbiota which activate the immune system at periodontal level.29-32 Gingival bleeding, as it is also known, decreased considerably in our study, in the experimental groups treated with ozone therapy. At the 6th month of treatment, it was shown predominance of sites without gingivorrhagia at examination (experimental group $\mathrm{D}$ by $95 \%$ ). Control group $\mathrm{Z}$ maintained more sites with gingivorrhagia by $35 \%$, because efficacy control of the subgingival microbiota or regulation of the defense systems of the host, which are properties attributed to ozone, may have not been achieved,.39

Similar result was obtained in a blind trial with 20 patients affected by chronic edematous gingivitis in one or more sectors of the mouse, between 15 and 50 years of age, where parameters evidenced, such as bleeding, edema, gum color, in which the Gingival Index is based on, decreased in the study and control groups. So, that recovery of patients treated with ozone was faster, shortening the term for evolution, was asserted. 38

Another research carried out by Dhingra K, Vandana KL ${ }^{40}$ shows that irrigation with ozonized 
water has good anti-inflammatory and anti microbial effects in periodontal tissues diminishing gingival bleeding.

Presence of periodontal pockets is another clinic characteristic of periodontitis. When comparing the experimental groups with the control group in relation to sites without pockets (up to $3 \mathrm{~mm}$ ), there was a predominance after the treatment, being more notable in experimental group D (combined treatment) by $97 \%$. However, control group Z still maintained a $20 \%$ of $4 \mathrm{~mm}$ pockets. The pockets are produced due to the rupture of the joint epithelium of epithelial adherence and migration in the apical sense of the periodonto for insertion, which is made evident after the action of the microbiota and its toxic products (enzymes, toxins and endotoxins) on epithelial structures creating gaps and invading the relying conjunctive tissues. ${ }^{38}$ From a theoretical point of view, it could be said that ozone and its derived products are introduced into these tissues forming molecular combinations that, on one side, neutralize the action of microorganisms and, on the other, strengthen the immune system's actions.

Some researchers as Păduraru A, Lăcătuşu S, Vataman $\mathrm{R}^{41}$ measured ozone therapy efficiency and have found out that it can be a complement of the periodontal treatment since it produces beneficial effects in the clinical evolution, evidenced in the X-rays. They suggest that it can contribute to osseous remineralization as much as other regenerative products.

In this research, at the sixth month of treatment, a decrease of the osseous loss was seen by only $2 \%$ in the sites by X-ray findings. In the control group, it was maintained sites with osseous loss by $5,5 \%$. It must be highlighted that in experimental group D non of the patients showed any X-ray sign of osseous loss, followed by Group A with an $0,6 \%$ only. Similar results as the aforementioned.

Osseous lysis, expressed in X-rays, in periodontitis, is the result of a process of combined aggressionresponse forces, where osteoclasts play a main role. This cell is responsible for the periodontal osseous reabsorption, in the same ways as the fibroblast is responsible for osseous formation. It seems that the osteoclast is activated by antigens derived from periodontal pathogens and they start the osseous destruction within the immune-inflammatory process. ${ }^{38,39,42}$ Ozone in any of its modalities can contribute with elements that inhibit this process and regulate the responses of fibroblasts, which synthesize collagen matrix for the regeneration of periodontal tissues.
According to Martínez Abreu $\mathbf{J}^{37}$, reactive metabolites or reactive species of oxygen play an important role in this process and ozone also contributes to regulate the equilibrium between them and the anti oxidant systems at the level of the cell which ensure recovery of processes and healing of the tissue lesion. These mechanisms influenced in the results of this study, where a satisfactory clinical evolution was evidenced with significant statistical differences between the groups, standing out the ozone gas, ozonized oil and combined treatments.

The role of microorganisms in periodontitis has been denominated as determinant, though in Cuba it is preferred to say that they are necessary, but not enough, since they influence other risk factors, such as social determinants of health.

What has been demonstrated indeed is that success of any periodontal treatment is closely linked to the subgingival microbiota control and to the elimination of periodontal pathogens.

Polydorou O, Halili A, Wittmer A, Pelz K, Hahn $\mathrm{P}^{43}$ are studying the effect of Healthozone in two types of microorganisms (Streptococcus mutans and Lactobacillus) where it is observed the antibacterial effect of ozone after only 60 seconds of treatment. On the other hand, Ripamonti CI, Cislaghi E, Mariani L, Maniezzo M. ${ }^{42}$ show good results at evaluating the effect of ozone the treatment of osteonecrosis of the mandible by biophosphonates.

These germicide effects are potent in OLEOZON (ozonized oil), due to the properties of its ozonides and peroxides; thus, contributing to results of the satisfactory microbiologic evolution that increased by $1,6 \%$ at the beginning of the study, by $85,4 \%$ at the $6^{\text {th }}$ month with experimental group D predominating.

According to some authors $28-43$ ozone therapy efficacy has been demonstrated in the control of different microorganisms, found in the buccal cavity, and also it is estimated that it contributes to reminerañli8zation of the dental and osseous structures.

Treatment studied showed a good efficacy by 85 , $4 \%$ in the total sample, predominating in the experimental group D (combined ozone therapy treatment) and being less in control group with significant statistical differences between the control group and the experimental ones.

The same results were obtained by Ripollés de Ramón J y col.44 at analyzing the periodontal responses from a clinical, microbiologic and immunologic point of view of a population with 
severe moderate periodontal pockets and their comparison, after ozone therapy with the technique of radicular scraping and smoothing. They found that periodontal treatment with ozone produces a significant statistical reduction of Lindhe Index for gingival bleeding, in the periodontal pathogenic microbiology, as well as in the immunologic patterns of IL1-b y el TNF-alfa. However, they do not coincide with our study regarding the level of periodontal insertion and depth of the periodontal pocket. There are experimental works 45,46 in models of endotoxic clash and lethal peritonitis where it is achieved, by means of application through rectal way, a reduction of specific pro inflammatory cytokines(IL-1, TNF-alfa), coinciding with what has been reported by Ripollés de Ramón J y col. ${ }^{44}$ In the studies reported by the reviewed literature $35-42,44$ there are not adverse events detected in the clinical trials, it is only commented on the possibility of a slight cough when ozone gas is employed, mainly when not all the necessary measures are taken during handling or if the patient is asthmatic or suffers from respiratory problems which constitutes one of the precautions of this modality. It has also been spoken of dryness of the laryng and in isolated cases of burning sensation, pruritus; coinciding with the study carried out where the percentage of adverse effects was very low.

In the last years an important advance has been made in the knowledge of the periodontal disease, form its multifactorial pathogeny, the microbiologic, the local immune response as well as multiple aspects in relation to its epidemiology an evolution process. Due to the greater knowledge in these fields, new techniques and pharmacological products are developed that try to stop the periodontal disease and preserve the buccal health. Ozone has become a very controversial gas, as well as its different therapeutic modalities. Its use dates from the XIX Century and has been employed in more than 260 different diseases. Its great oxidant power and germicide character have been its most studied properties. However, controlled clinical trials are still required so that the scientific community accepts this therapeutic modality as an aid of great value in the stomalogical treatments.

The authors wish, with this research, to provide a modest contribution to the world's scientific community so as to create the necessary conditions at universities and research institutes and to devote material, financial and human resources to the study of dental ozone therapy due to its benefits in order to improve buccal health on the whole

\section{REFERENCES}

1. Azarpazhooh A, Limeback H. The application of ozone in dentistry: a systematic review of literature. J Dent. 2008;36:104-116.

2. Lynch E. Ozone: The Revolution in Dentistry. Chicago: Quintessence Publishing; 2004.

3. Bocci V. Ozone as a bioregulator. Pharmacology and toxicology of ozone therapy today. J Biol Regul Homeost Agents. 1996;10:31-53.

4. Sagai M, Bocci V. Mechanisms of Action Involved in Ozone Therapy: Is healing induced via a mild oxidative stress. Med Gas Res. 2011;1(1). doi: 10.1186/2045-9912-1-29.

5. Garg R, Tandon S. Ozone: A new face of dentistry. The Internet Journal of Dental Science. 2008;7(2). Available from: http:// ispub.com/IJDS/7/2/6215

6. Saini R. Ozone therapy in dentistry: A strategic review. Journal of natural science, biology, and medicine. 2011;2(2):151-153. PubMed PMID: 22346227.
7. Bhateja S. The miraculous healing therapy? Ozone therapy? In dentistry. Indian Journal of Dentistry. 2012;3(3):150-155.

8. Bocci V, Zanardi I, Travagli V. Oxygen/ozone as a medical gas mixture. A critical evaluation of the various methods clarifies positive and negative aspects. Medical Gas Research. 2011;1(6). doi: 10.1186/2045-9912-1-6.

9. Loncar B, Stipetic MM, Matosevic D, Tarle Z. Ozone Application in Dentistry. Archives of Medical Research. 2009;40(2):136-137.

10. Estrela C, Estrela CRA, Decurcio DA, Hollanda ACB, Silva JA. Antimicrobial efficacy of ozonated water, gaseous ozone, sodium hypochlorite and chlorhexidine in infected human root canals. Int Endodont J. 2007;40:85-93.

11. Menendez S, Fernandez M, Amoroto M, Uranga R, Acuña P, Benitez JE, et al. Eficacia y seguridad del Oleozon ${ }^{\circledR}$ topico en el tratamiento de pacientes con impetigo. Rev 
Panamericana de Infectologia. 2007;9(2): 23-29.

12. Bocci V. Ozone as Janus: This controversial gas can be either toxic or medically useful. Mediators of Inflammation. 2004;13(1):3-11. doi: 10.1080/0962935062000197083.

13. Bocci V. Tropospheric Ozone Toxicity vs. Usefulness of Ozone Therapy Arch Medical Res. 2007;38(2):265-267.

14. Bocci V. Is it true that ozone is always toxic? The end of a dogma. Toxicol Appl Pharmacol. 2006;216(3):493-504.

15. Cruz O, Menendez S, Reyes O, Díaz W. Aplicación de la ozonoterapia en el tratamiento de los conductos radiculares infectados. Revista Cubana de Estomatología. 1994;31:14-18.

16. Falcon L, Simon R, Menendez S. Aceite ozonizado en dermatologia. Experiencia de 9 años. Revista CENIC Ciencias Biologicas. 1998;29:192-9.

17. Menendez S, Falcon L, Simon DR, Landa N. Efficacy of OLEOZON $\AA$ in the treatment of tinea pedis. Mycoses. 2002;45:329-332.

18. Amoroto M, Fernandez M, Gonzalez ME, Escobedo A, Palomino A, Acosta M. Eficacia del aceite ozonizado (OLEOZON®) en el tratamiento de la giardiasis. Ensayo clínico fase III, aleatorizado, abierto y controlado. Rev. Cubana de Farmacia. 2002;36(2):173-175.

19. Garcia E, Roche A, Blanco AC, Rodriguez LO. La ozonoterapia en el tratamiento de la estomatitis subprotesis. Rev Cubana Estomatol. 2003;40(2):6-10.

20. Lezcano I, Moleiro J, Gomez M. Actividad in vitro del OLEOZON® frente a agentes etiologicos de infecciones en la piel. Revista CENIC Ciencias Biologicas. 1998;29:209-212.

21. Martinez G, Merino N, Sam S, Cenarega T. Efecto histologico y bioquimico del OLEOZON® en el modelo de la cola de raton. Revista CENIC Ciencias Biologicas. 1997;28:31-35.

22. Acevedo F, Gonzalez J, Moleiro J. Ensayo de toxicidad dermica de 120 días del aceite ozonizado, OLEOZON®, en ratas Cenp. SPRD. Avances en Biotecnología Moderna. 1997;4.

23. Arteaga ME, Molerio J, Bada A, Gonzalez B, Zamora Z, Remigio AC. Clasificacion toxicologica del OLEOZON®. Rev CENIC Ciencias Biologicas. 2000;32(1):57-59.
24. Remigia A, Gonzalez Y, Zamora Z, Molerio J. Evaluacion genotoxica del Oleozon ${ }^{\circledR}$. Rev CENIC Ciencias Biologicas. 1998;28:100-104.

25. Martinez G, Leon OS, Rodriguez C, Merino N. Estudio de la toxicidad aguda dermica del aceite ozonizado OLEOZON® en ratas. Revista CENIC Ciencias Biologicas. 1997;28:35-41.

26. Llerena C, Moleiro J, Garcia C. Prueba de sensibilizacion del aceite ozonizado. Registro medico OLEOZON ${ }^{\circledR}$ pinceladas. Aplicación en epidermofitosis. Registro Sanitario No. 1498. Cuba: Centro para el Control Estatal de Calidad de los Medicamentos de la Republica de Cuba; 1999.

27. Unknown-authors . Programa Nacional de Medicina Natural y Tradicional. La Habana, Cuba: Editorial Ciencias Medicas; 2008.

28. Gupta G, Mansi B. Ozone therapy in periodontics. J Med Life. 2012;5(1):59-67. PubMed PMID: 22574088.

29. Eick S, Tigan M, Sculean A. Effect of ozone on periodontopathogenic species - an in vitro study. Clinical Oral Investigations. 2011;16:537-544.

30. Johansson E, Claesson R, van-Dijken JW. Antibacterial effect of ozone on cariogenic bacterial species. J Dent. 2009;37:449-453.

31. Burgassi S, Zanardi I, Travagli V, Montomoli E, Bocci V. How much ozone bactericidal activity is compromised by plasma components. J Appl Microbiol. 2009;106:1715-1721.

32. Sharma M, Hudson JB. Ozone gas is an effective and practical antibacterial agent. Am J Infect Control. 2008;36:559-563.

33. Yamada K, Yama M, Takaku Y, Kakizawa T, Kimizuka R, Okuda K, et al. Antimicrobial activity of super-oxidised water against oral microorganisms. Arch Oral Biol. 2010;55:397-400.

34. Huth KC, Quirling M, Maier S, Kamereck K, Alkhayer M, Paschos E, et al. Effectiveness of ozone against endodontopathogenic microorganisms in a root canal biofilm model. Int Endod J. 2009;42:3-13.

35. Mayor-Hernandez F, Martinez-Abreu J, MoureIbarra MD, Garcia-Valdes MR. Aplicacion del OLEOZON ${ }^{\circledR}$ en el tratamiento de las pericoronaritis. Rev Med Electron. 2011;33(1). Available from: http://www.revmatanzas.sld.cu/ 
revista\%20medica/ano\%202011/vol1\%202011/ tema11.htm

36. Martinez-Abreu J, Chapelin-Arencibia Y, PeñaRuiz T. OLEOZON® en el tratamiento de la gingivitis cronica edematosa. Rev Med Electron. 2006;28(6). Available from: http:// www.cpimtz.sld.cu/revista $\% 20$ medica/ ano\%202006/vol6\%202006/tema05.htm

37. Martinez-Abreu J, Peña-Ruiz T, Llanes-Llanes E, Ilzarbe LM. Papel de los metabolitos reactivos del oxigeno en los periodontopatias. Rev Med Electron. 2007;29(5). Available from: http://www.cpimtz.sld.cu/revista\%20medica/ ano\%202007/vol5\%202007/tema15.htm

38. Martinez-Abreu J. OLEOZON ${ }^{\circledR}$ en el tratamiento del absceso periodontal agudo en pacientes diabeticos [thesis]. Cuba: Universidad de Ciencias Medicas de Matanzas; 2009.

39. Nogales CG, Ferrari PH, Kantorovich EO, Lage-Marques JL. Ozone therapy in medicine and dentistry. J Contemp Dent Pract. 2008;9:75-84. PubMed PMID: 18473030.

40. Dhingra K, Vandana KL. Management of gingival inflammation in orthodontic patients with ozonated water irrigation--a pilot study. Int J Dent Hyg. 2011;9(4):296-302. doi: 10.1111/j.1601-5037.2011.00506.x.

41. Paduraru A, Lacatusu S, Vataman R. Ozone therapy efficiency and gerovital $\mathrm{H} 3$ as an additional way to the complex treatment of periodontal disease. Rev Med Chir Soc Med
Nat Iasi. 2010;114(3):880-884. PubMed PMID: 21243820.

42. Ripamonti CI, Cislaghi E, Mariani L, Maniezzo M. Efficacy and safety of medical ozone $(\mathrm{O}(3))$ delivered in oil suspension applications for the treatment of osteonecrosis of the jaw in patients with bone metastases treated with bisphosphonates: Preliminary results of a phase I-II study. Oral Oncol. 2011;47(3):185-190. PubMed PMID: 2131065.

43. Polydorou O, Halili A, Wittmer A, Pelz K, Hahn P. The antibacterial effect of gas ozone after 2 months of in vitro evaluation. Clin Oral Investig. 2012;16(2):545-550. PubMed PMID: 21331635.

44. Ripolles-de-Ramon J, Colmenero-Ruiz C, Gallut-Ruiz J, Zaera-Le-Gal R, BastonesMartinez A. Evaluacion clinica, microbiologica e inmunologica de la ozonoterapia en pacientes con bolsas periodontales moderadas-severas. Av Periodon Implantol. 2004;16(1):63-72.

45. Bette M, Mutters R, Nusing RM, Rodríguez ZZ, Menendez S, Schulz S. Efficiency of Piperacillin/Tazobactam in lethal peritonitis is enhanced after preconditioning of rats with an oxidative stressor. Shock. 2006;25(1):23-29.

46. Zamora Z, Borrego A, Lopez O, Delgado R, Gonzalez R, Menendez S, et al. Effects of ozone oxidative preconditioning on TNF-alfa release and antioxidant-prooxidant intracellular balance in mice during endotoxic shock. Mediators of Inflammation. 2005;1:16-22. 